\title{
Profiling the immune response to TB infection on a genome-wide scale with protein microarrays
}

\author{
Philip Felgner \\ From Immunodiagnosis of Tuberculosis: New Questions, New Tools \\ Virginia, VA, USA. 21-23 September 2008
}

The process for fabrication of a microarray from genomic DNA for whole proteome microarrays for B. pseudomallei may have application for Mycobacterium tuberculosis (M.tb). In the process, PCR is done on the DNA to amplify the open reading frames, genes are cloned by in vivo recombination, and mini-preps are made, isolating the plasmids produced by the recombination process. Then, in vitro transcription and translation reactions occur. Lastly, the reactions are brought to a microarray printer and the microarray chips are printed, using nitrocellulose-coated slides and without doing protein purification. The heart of the process is the high throughput cloning approach our team developed. Twenty nucleotide extensions are added to the PCR products so that the genes, although all different, have the same $\mathrm{N}$-terminal and $\mathrm{C}$-terminal sequences. The gene-specific primers are homologous with 33 nucleotide vector-specific 'adapter' sequences. The plasmids are transformed into chemically competent $E$. coli and grown overnight. The protein produced in the in vitro transcription and translation reactions, driven by a T-7 promoter, has both a HIS tag and a HA tag. The efficiency rate for producing clones by this method is greater than 95 percent, based on an analysis of 4,109 gene targets that produced 3,998 cloned genes. To test protein expression efficiency, we probed two arrays with monoclonal antibodies and then a secondary antibody. Out of 11 print runs, 2,265 chips produced 4,530 arrays, or a greater than 90 percent protein expression efficiency rate. Finally we tested batch-to-batch reproducibility by taking two batches of chips and track the signal of the HIS tag.

Correspondence: pfelgner@uci.edu

Applied Proteomics Research Laboratory, University of California at Irvine, Irvine, California, USA
In a case-control M.tb study, our lab examined smear positive culture test results in individuals from endemic countries and from healthy individuals in non-endemic countries. In a series of projects involving 25 infectious disease agents, our lab has produced 18,000 proteins, printed 17,000 arrays, and probed 8,000 sera. The goal of this research, is to develop multi-variant microarray chips that contain several antigens, so that only one blood sample is required from an individual to determine a diagnosis.

Published: 17 December 2010

doi:10.1186/1753-6561-4-S3-017

Cite this article as: Felgner: Profiling the immune response to TB infection on a genome-wide scale with protein microarrays. BMC Proceedings 2010 4(Suppl 3):017.

Submit your next manuscript to BioMed Central and take full advantage of:

- Convenient online submission

- Thorough peer review

- No space constraints or color figure charges

- Immediate publication on acceptance

- Inclusion in PubMed, CAS, Scopus and Google Scholar

- Research which is freely available for redistribution 